Iryna Tychyna, PhD (Candidate of Psychological Sciences), associate professor, Department of Social and Applied Psychology, Zhytomyr State University named after Ivan Franko, 40, Velyka Berdychivska Str., Zhytomyr, Ukraine

\title{
INTRAPSYCHIC MONODRAMA AS A METHOD OF LEARNING AND SEARCHING FOR INTERNAL RESOURCES OF PERSONAL DEVELOPMENT
}

One of the main human qualities is the ability of individuals to think about themselves, their destination, true desires and life goals. The development of self-reflection and self-mastery techniques not only promotes better selfunderstanding, but also helps to see one's strengths, identify areas of the development. In this regard, methods of using psychodrama techniques in individual counselling with a view to open the inner nature of client's identity are relevant. The article is aimed at analysing the feasibility of psychodrama ideas in monodrama game in the counselling process and identifying the main steps in the method of intrapsychic monodrama. Monodrama is considered as a variant of psychodrama, when all the roles are played by the protagonist himself. Room space is used to build the scene, empty chairs or symbolic objects play the role of other people. Monodrama game, depending on the problems raised by a client, can be different: interpersonal, fantastic, intrapersonal. The sequence of operation in the method of intrapersonal monodrama may include three steps. The first step involves meeting with a mask, in order to understand why it is necessary and what kind of role it is. The second step involves the identification of roles the mask hides. At this step the realisation of the whole repertoire of a personality is possible. The third step is the final one, in which the analysis of the repertoire of the protagonist' roles for the development of the "Ego", takes place. Intrapsychic monodramatic work makes it possible to see and understand all the role-parts of the "Ego" which are willingly demonstrated to someone and securely hidden from others. Besides, intrapsychic psychodramatic experiments provide an opportunity to learn more about oneself for oneself, oneself for a group, for a society and humanity as a whole.

Keywords: psychodrama, monodrama, intrapsychic monodrama, interpersonal monodrama, fantastic monodrama, protagonist.

Подано до редакияії 14.04.2016

УДК: 159.922

Тетяна Миколаӥвна Шапран, асистент кафедри сочіальної та практичної психології, Житомирський державний університет імені Івана Франка, вул. Велика Бердичівська, 40, м. Житомир, Украӥна

\section{ВИКОРИСТАННЯ МОТИВІВ СИМВОЛДРАМИ В РОБОТІ 3 ВНУТРІШНИМИ КОНФЛІКТАМИ ОСІБ ЮНАЦЬКОГО ВІКУ}

У статті розглянуто різні підходи до визначення змісту поняття «внутрішній конфлікт». У межах глибинної психології, в межах біхевіористичної школи, гуманістичної психології та екзистенціального напрямку психології. У статті подано результати емпіричного дослідження роботи з внутрішніми конфліктами юнаків. Обтрунтовано доцільність використання кататимно-імагінативного методу (символдрами) у роботі $з$ внутрішніми конфліктами осіб юнацького віку. Виявлено та описано закономірності пропращювання внутрішноособистісних конфліктів особами юначького віку за допомогою мотивів символдрами.

Ключові слова: внутрішньоособистісний конфлікт, юнаџький вік, кататимно-імагінативний метод, символдрама, мотив, метод семантичного диференціалу.

У період юнацтва продовжується становлення особистості та перебудова взаємостосунків 3 дорослим оточенням. Юнаки та дівчата намагаються здобути автономність від батьків та поширити ії на усі сфери власної життєдіяльності. Вікові суперечності становлення особистості стимулюють виникнення відчуття самотності, що призводить до бажання юнаків спілкуватися з однолітками. Все це спричинює непорозуміння $з$ боку батьків та дуже часто обумовлює виникнення внутрішніх конфліктів у самих юнаків. Оскільки тривале знаходження під впливом внутрішніх конфліктів може призвести до виведення особистості 3 психічної рівноваги, перед нами постало питання пропрацювання внутрішніх конфліктів юнаками.

Мета статті полягає в обгрунтуванні доцільності використання кататимно-імагінативного методу у роботі з внутрішніми конфліктами юнаків. 
Упродовж всього свого життя людина зустрічається 3 вибором. 3 вибором своїх дій, вчинків, мотивів поведінки тощо. Іноді цей вибір унеможливлюється через внутрішні переконання особистості. Це призводить до виникнення внутрішньоособистісних конфліктів.

Аналізуючи зарубіжну та вітчизняну наукову літературу, ми прийшли до висновку, що не існує єдиного підходу до визначення змісту поняття «внутрішній конфлікт». Так, в межах глибинної психології наукове вивчення внутрішніх конфліктів розпочинається в межах психоаналітичної теорії 3. Фройда. Засновник психоаналізу вбачав внутрішньо особистісний конфлікт у суперечностях і постійній боротьбі біологічних потягів i бажань людини 3 соціальнокультурними нормами ії оточення - між такими структурними компонентами особистості як «Воно» та «Над-Я». Його учень-послідовник, засновник індивідуальної психології А. Адлер розглядав внутрішній конфлікт як боротьбу між почуттям власної меншовартості та прагненням до ії подолання. Ще один учень 3. Фройда, засновник аналітичної психології К.Г. Юнг вважав, що внутрішній конфлікт можливий між особистим Я та архетипом. Представниця неофрейдизму К. Хорні внутрішньоособистісний конфлікт бачила між взаємовиключними потребами чи суперечливими «невротичними потягами».

Представник біхевіористичної школи Б. Скіннер розглядав внутрішній конфлікт як сукупність реакцій, які виступають результатом хибного сприйняття людини. Вчений німецької психологічної школи К. Левін визначав внутрішньоособистісний конфлікт як ситуацію вибору між двома рівновеликими силами, що мають протилежне спрямування. Психологи-гуманісти розглядали внутрішньоособистісні конфлікти як дисонанс між «Я-концепцією» особистості та ії уявленням про «Ідеальне Я» (К. Роджерс), між прагненням до самоактуалізації та реальним результатом (А. Маслоу). Співвітчизник 3. Фройда, представник екзистенціального напрямку психології та засновник логотерапевтичного напрямку в психотерапії В. Франкл внутрішній конфлікт вбачав у екзистенціальному вакуумі, що являє собою відсутність сенсу буття, почуття безцільності та порожнечі.

Вітчизняними психологами зміст внутрішнього конфлікту також розглядався в межах різних психологічних напрямків. Так, у теорії діяльності внутрішній конфлікт обумовлений характерними структурними компонентами особистості (мотиви, цілі), що детерміновані суперечливими стосунками під час здійснення різноманітних видів діяльності (В.М. Мясищєв, В.С. Мерлін, О.М. Леонтьєв), у теорії розвитку особистості - як психічне явище, що супроводжує процес розвитку особистості у період вікових криз (Л.С. Виготський, Л.І. Божович). Сучасні праці Ф.Є. Василюка, А.Я. Анцупова, А.І. Шипілова розглядають конфлікт як критичну життєву ситуацію, а дослідження В.В. Століна - як умову розвитку самосвідомості.
Таким чином, ми дійшли висновку, що і зарубіжні, і вітчизняні вчені трактують зміст внутрішнього конфлікту в межах власних психологічних підходів, проте спільним для всіх поглядів $є$ розуміння внутрішньоособистісного конфлікту як зіткнення різноспрямованих бажань людини, протистояння однієї частини особистості іншій, суперечливе ставлення індивіда до інших людей і самого себе.

Юність - це період здобутку власного внутрішнього світу, становлення світогляду особистості, формування особистісної ідентичності та відкриття власного «Я». Усі ці пошуки осіб юнацького відбуваються поступово та суперечливо і слугують гарним підгрунтям для виникнення внутрішніх конфліктів.

Аналіз сучасної наукової літератури показав, що переважна більшість дисертаційних досліджень внутрішьоособистісних конфліктів базується на методиках російської дослідниці О.Б. Фанталової. Вона запропонувала комплекс методик, метою яких $є$ діагностика домінуючих цінностей і конфліктів особистості, а також способів їх емоційної переробки, що, в свою чергу відображають глибоку індивідуальність та специфічність функціонування психологічного захисту. Так, за допомогою методики «Рівень співвідношення «цінності» та «доступності» в різних життєвих сферах» $[5$, с.8] виділяються сфери неспівпадання між найсуттєвішими для особистості цінностями та мірою їх доступності, що свідчить про дезінтеграцію ціннісно-мотиваційної сфери особистості і, як наслідок, наявність внутрішнього конфлікту. Наступна методика «Сім станів» [5, с.12] діагностує індивідуальну специфіку емоційних переживань конфліктів, їх зміст та інтенсивність. Результати методики «Шкала оцінки дискомфорту» [5, с.13] дають можливість зіставити об'єктивно встановлений рівень розбіжності між «цінністю» i «доступністю» у мотиваційноособистісній сфері та ступінь дискомфорту, що особистість переживає суб'єктивно. I останньою методикою 3 системи «Діагностики внутрішнього конфлікту» О.Б.Фанталової є методика «Вільний вибір цінностей» [5, с.15], що завдяки вільному, індивідуальному для кожного досліджуваного вибору цінностей із запропонованого списку, дозволяє здійснити подальше дослідження «ціннісного ядра суб'єкта».

Таким чином, комплексний підхід до діагностики внутрішніх конфліктів особистості у науковій літературі представлений. Проте питання комплексного підходу до пропрацювання внутрішнього конфлікту особистості залишається ще недостатньо вивченим. Саме тому нами була здійснена спроба застосування кататимно-імагінативного методу у роботі з внутрішніми конфліктами осіб юнацького віку.

Кататимно-імагінативний метод або символдрама - це напрямок роботи, що базується на принципах глибинної психології, в якому використовується особливий метод роботи 3 уявою для унаочнення несвідомих бажань, фантазій, конфліктів та механізмів захисту особистості. Метод був розроблений відомим 
німецьким психотерапевтом Ханскарл Льойнером [2] на основі концепції класичного психороаналізу, а також його сучасного розвитку - теорії об'єктних відносин М. Кляйн, его-психології Г.Фройд, психології «Я» Х. Хартманна та селф-психології Х. Когута. Концептуальною основою методу стали глибиннопсихологічні психоаналітично орієнтовані теорії, аналіз несвідомих і підсвідомих конфліктів, афективноінстинктивних імпульсів, процесів і механізмів захисту як відображення актуальних емоційноособистісних проблем та аналіз онтогенетичних форм конфліктів раннього дитинства. Багато спільного символдрама має і з теорією архетипів і колективного несвідомого К.Г. Юнга, а також $з$ розробленим цим вченим методом активної уяви.

В основі методу символдрами лежить вільне фантазування особистості у формі образів на задану психологом тему, що має назву мотив. Пропозиція мотиву представлення образу необхідна для кристалізації образної фантазії особистості.

При роботі 3 внутрішніми конфліктами юнаків часто залишається нерозкритою глибинна несвідома проблематика оскільки в дію вступають психологічні механізми захисту та опору, що приховують важливі несвідомі та підсвідомі конфлікти та страхи. Перевагою роботи з юнаками методом символдрами $є$ те, що створюється сприятлива атмосфера для праці 3 глибинними, прихованими від свідомості переживаннями, стає можливим поступове поетапне пропрацювання внутрішніх конфліктів 3 одночасним урахуванням складної динаміки усвідомлюваних і неусвідомлюваних психологічних механізмів захисту та опору.

Таким чином, саме мотиви методу символдрами були обрані нами для поетапного пропрацювання внутрішніх конфліктів, пов'язаних із батьками в осіб юнацького віку.

Дослідження проводилось на базі Будівельного коледжу Житомирського національного агроекологічного університету впродовж 2015-2016 років. Вибірку склали 9 студентів юнацького віку: 3 них 4 особи чоловічої та 5 осіб жіночої статі. У студентів було виявлено наявність внутрішнього конфлікту, пов'язаного з батьками. Дослідження проходило у три етапи.

На першому етапі дослідження для 3'ясування змісту індивідуальних значень внутрішнього конфлікту студентів ми використали метод семантичного диференціалу Ч. Осгуда. На другому етапі для поетапного пропрацювання юнаками внутрішніх конфліктів, пов'язаних із батьками, зокрема матерями, ми використовували мотиви методу символдрами. На третьому етапі дослідження 3 метою з'ясування динаміки змін реакції на внутрішній конфлікт ми знову застосували метод семантичного диференціалу.

Метод семантичного диференціалу Ч. Осгуда був обраний нами для кількісного та якісного індексування значень при вимірюванні поведінкової реакції студентів на слова-стимули, що умовно-рефлектовно пов'язані з їхньою загальною реакцією на внутрішній конфлікт, який позначався цими словами-стимулами.

Ми скористалися 12-шкальним варіантом методики, де в ролі шкал для оцінки досліджуваних стимулів-понять пропонуються: «хороший-поганий», «важкий-легкий», «швидкий-повільний», «красивийбридкий», «активний-пасивний», «великиймаленький», «теплий-холодний», «чистий-брудний», «сильний-слабкий», «ласкавий-жорстокий», «шалений-спокійний», «товстий-тонкий».

Шкали передбачали такі градації оцінки стимулу: +3 (сильно виражена ознака), +2 (середньо), +1 (слабо), 0, -1 (слабо), -2 (середньо), -3 (сильно виражена полярна ознака).

Перед початком дослідження ми визначили ті поняття, які найчастіше зустрічалися у характеристиці студентами власного сприймання внутрішнього конфлікту, пов'язаного з батьками. Саме тому вони можуть бути використані як стимули-поняття в методиці семантичного диференціалу. Всього було виділено п’ять таких понять, а саме: стрес, роздратованість, напруга, депресія та розгубленість.

Обрана методика семантичного диференціалу передбачає розрізнення таких трьох узагальнюючих факторів, як «оцінка», «сила» та «активність».

Обробка результатів дослідження проводилася наступним чином:

- за шкалами семантичного диференціалу респонденти приписували стимулам-поняттям числові значення від +3 до -3 ;

- для кожного стимулу-поняття складалися таблиці значень факторів «оцінка», «сила», «активність» для кожного з обстежуваних;

- для кожного 3 п'яти понять-стимулів розраховувалися середні значення показників факторів «оцінки», «сили» та «активності»;

- узагальнені значення факторів «оцінка», «сила» та «активність» для студентів на першому етапі дослідження (до пропрацювання внутрішніх конфліктів) та на третьому етапі дослідження (після пропрацювання внутрішніх конфліктів) представлені у таблиці 1.

Передусім звернемо увагу на виражено нижчі значення фактору «оцінка», продемонстровані студентами для більшості запропонованих стимулів на першому етапі застосування методу. Вважаємо, що отримані дані пов'язані зі слабкою диференціацією студентами власних емоційних станів, в силу чого виявилося, що їм важче висловлювати оцінні судження про поняття-стимули, пов'язані з внутрішнім конфліктом, ніж оцінювати «силу» та «активність» останніх. На третьому етапі дослідження після пропрацювання внутрішніх конфліктів мотивами символдрами за усіма стимулами-поняттями значення фактору «оцінка» збільшилися.

На ту обставину, що після пропрацювання внутрішніх конфліктів мотивами символдрами ланцюжок емоційного реагування не став належним чином ком- 
понентом їхньої активності, вказує певна негативна динаміка значень факторів «активність» та «сила» на третьому етапі проведеного дослідження.

Таблиця 1 .

Значення факторів «оцінка», "сила» та «активність»

(порівняльні дані студентів до та після застосування мотивів символдрами, у балах)

\begin{tabular}{|l|l|c|c|}
\hline Стимули-поняття & Фактори & Перший етап & Третій етап \\
\hline \multirow{3}{*}{ Стрес } & оцінка & $-6,7$ & $-2,8$ \\
\cline { 2 - 4 } & сила & 5,0 & $-6,0$ \\
\cline { 2 - 4 } & активність & 7,7 & $-1,0$ \\
\hline \multirow{3}{*}{ Роздратованість } & оцінка & $-5,3$ & 0,5 \\
\cline { 2 - 4 } & сила & 10,3 & $-1,5$ \\
\cline { 2 - 4 } & активність & 10,2 & $-0,6$ \\
\hline \multirow{3}{*}{ Напруга } & оцінка & 0,7 & 3,3 \\
\cline { 2 - 4 } & сила & 9,7 & $-2,7$ \\
\cline { 2 - 4 } & активність & 6,3 & $-2,6$ \\
\hline \multirow{3}{*}{ Депресія } & оцінка & $-9,3$ & $-4,3$ \\
\cline { 2 - 4 } & сила & 5,0 & $-7,6$ \\
\cline { 2 - 4 } & активність & $-11,3$ & $-0,5$ \\
\hline \multirow{2}{*}{ Розгубленість } & оцінка & $-3,0$ & $-5,0$ \\
\cline { 2 - 4 } & сила & 6,7 & $-3,2$ \\
\cline { 2 - 4 } & активність & $-2,8$ & \\
\hline
\end{tabular}

Певну суперечність зі сказаним виражає значення фактора «активність», отриманого для стимулу «розгубленість», оскільки він виявився незначною мірою вищим на третьому етапі дослідження, ніж на першому. Водночас цю суперечність легко пояснити побутовими причинами, оскільки респондентам необхідно перенести новий, переосмислений, набутий в ході пропрацювання внутрішніх конфліктів досвід у реальне життя, що може спричинити певну розгубленість та неготовність до цього студентів. Сказане, зрозумі-

\section{ЛІТЕРАТУРА}

1. Заброцький М.М. Основи вікової психології. Навчальний посібник / М. М. Заброцький. - Тернопіль: Навчальна книга - Богдан, 2002. - 112 с.

2. Лёйнер $\mathrm{X}$. Средняя ступень символдрамы. Возможности средней ступени / X. Лейнер / Пер. с нем. О. Хмельницкой, научная редакция 3.Г. Кисарчук и Я.Л. Обухова // Символдрама. - 2011, №1(6). C. $4-8$.

\section{REFERENCES}

1. Zabrotskyi, M. M. (2002). Osnovy vikovoi psykhologhii. Navchalnyi posibnyk [Fundamentals of psychology. Tutorial]. Ternopil: Navchalna knyha. Boghdan [in Ukrainian].

2. Leiner, Kh. (2011). Sredniaya stupen simvoldramy. Vozmozhnosti srednei stupeni [The average level of symboldrama. Opportunity an average degree]. Simvoldrama - Simvoldrama, 1(6), 4-8 [in Russian].

3. Obukhov, Y. L. (1997). Simvoldrama. Katatimno-imaginativnaia psikhoterapiia detei $i$ podrostkov [Simvoldrama. Katatimno-imaginative ло, не заперечує наявності певної позитивної динаміки смислового насичення семантичного простору стимулів-понять, які виявляють сутність внутрішніх конфліктів осіб юнацького віку.

Таким чином, можемо констатувати доцільність використання кататимно-імагінативного методу у пропрацюванні внутрішніх конфліктів особами юнацького віку. Перспективу своїх подальших досліджень вбачаємо у виявлені гендерних особливостей внутрішніх конфліктів осіб юнацького віку.

3. Обухов Я.Л. Символдрама. Кататимноимагинативная психотерапия детей и подростков / Я. Л. Обухов. - М.: Эйдос, 1997. - 112 с.

4. Обухов Я. Основи символдрами. Вступ до основного ступеня / Я. Обухов. - К.: Главник, 2007. $112 \mathrm{c}$.

5. Фанталова Е. Б. Диагностика и психотерапия внутреннего конфликта / Е. Б. Фанталова. - Самара: Издательский дом БАРАХ-М, 2001. - 62 с.

psychotherapy children and adolescents]. Moscow: Eidos. [in Russian].

4. Obukhov, Ya. (2007). Osnovy symvoldramy. Vstup do osnovnogho stupenia [Basics simvoldramy. Admission to the main stage]. Kyiv: Glavnik [in Ukrainian].

5. Fantalova, E. B. (2001). Diagnostika $i$ psikhoterapiia vnutrennego konflikta [Diagnosis and therapy of internal conflict]. Samara: Izdatelskii dom BARAKh-M [in Russian]. 
Татьяна Николаевна Шапран,

ассистент кафедры социальной и практической психологии, Житомирский государственный университет имени Ивана Франко, ул. Большая Бердичевская, 40, г. Житомир, Украина

\section{ИСПОЛЬЗОВАНИЕ МОТИВОВ СИМВОЛДРАМЫ В РАБОТЕ С ВНУТРЕННИМИ КОНФЛИКТАМИ ЛИЦ ЮНОШЕСКОГО ВОЗРАСТА}

В статье рассмотрены различные подходы к определению содержания понятия «внутренний конфликт». В рамках глубинной психологии научное изучение внутренних конфликтов проанализированы с позиции психоаналитической теории 3. Фрейда, индивидуальной психологии А. Адлера, аналитической психологии К.Г. Юнга. С позиции неофрейдизма - в рамках теории К. Хорни. Среди других зарубежных направлений внутриличностный конфликт рассмотрено в пределах бихевиористичнои школы Б. Скиннера, немецкой психологической школы К. Левина, гуманистической психологии К. Роджерса, А. Маслоу и экзистенциального направления психологии В. Франкла. Среди отечественных психологов содержание внутреннего конфликта рассмотрено в теории деятельности В.М. Мясищева, В.С. Мерлина, А.Н. Леонтьева, теории развития личности Л.С. Выготского и Л.И. Божович. Также содержание внутриличностного конфликта рассмотрены в работах современных исследователей - Ф.Е. Василюка, А.Я.Анцупова, А.И. Шипилова и В.В. Столина. Проанализировав научную литературу, установлено, что не существует единого подхода к определению содержания понятия «внутренний конфликт». И зарубежные, и отечественные ученые трактуют содержание внутреннего конфликта в пределах собственных психологических подходов, однако общим для всех взглядов является понимание внутриличностного конфликта как столкновения разнонаправленных желаний человека, противостояние одной части личности другой, противоречивое отношение индивида к другим людям и самому себе. Относительно диагностики внутренних конфликтов личности выявлено, что подавляющее большинство диссертационных исследований внутришьоособистисних конфликтов базируется на методиках российской исследовательницы О.Б. Фанталовой. Ученый предложил систему «Диагностика внутреннего конфликта», состоящий из комплекса четырех методик: «Уровень соотношения «ценности» и «доступности» в различных жизненных сферах», «Семь состояний», «Шкала оценки дискомфорта» и «Свободный выбор ценностей». Таким образом комплексный подход к диагностике внутренних конфликтов личности в научной литературе представлен. Однако вопрос комплексного подхода к проработки внутреннего конфликта личности остается еще недостаточно изученным. Именно поэтому нами была предпринята попытка применения кататимно-имагинативной метода в работе с внутренними конфликтами лиц юношеского возраста. В статье представлены результаты трех этапов эмпирического исследования работы с внутренними конфликтами юношей. Обоснована целесообразность использования кататимноимагинативной метода (символдрамы) в работе с внутренними конфликтами лиц юношеского возраста. Выявлены и описаны закономерности проработки внутришноособистисних конфликтов лицами юношеского возраста с помощью мотивов символдрамы.

Ключевые слова: внутриличностный конфликт, юношеский возраст, кататимно-имагинативной метод, символдрама, мотив, метод семантического дифференциала.

Tetiana Shapran, pssistant of the Department of Social and Practical Psychology, Zhytomyr State University named after Ivan Franko, 40, Velyka Berdychivska Str., Zhytomyr, Ukraine

\section{USE OF THE CATATHYMIC AND IMAGINATIVE METHOD IN DEALING WITH INTERNAL CONFLICTS IN ADOLESCENCE}

The article is aimed at substantiating the appropriateness of using the catathymic and imaginative method of dealing with inner conflicts of adolescents. The catathymic and imaginative method or guided affective imagery (or symboldrama) is based on the principles of depth psychology, which uses the special method of working with imagination for visualisation of person's unconscious fantasies, desires, and conflicts. It involves free dreaming in the form of imaginations on the topic proposed by a psychologist. The study involved 9 students-adolescents $(4$ male and 5 female students). All the respondents had inner conflicts associated with their parents. The experiment was carried out in three stages. The first one was aimed at revealing the essence of the personal ideas about the inner conflicts by the students by means of Semantic differential method by C. Osgood. The second one involved the use of catathymic and imaginative method in order to deal with the respondents' inner conflicts connected with their mothers. At the third stage, the method of C. Osgood was used again in order to assess the changes of the respondents' respond to the inner conflicts. The research results have shown that the majority of the adolescents demonstrated low indices of the "assessment" factor for the most of the proposed stimuli at the first stage of the experiment. It is associated with the respondents' poor ability to differentiate their emotional states. At the third stage after consideration of the inner conflicts by means of 
guided affective imagery according to all stimuli, the indices of factors "assessment" have increased. Thus, the research results prove the expediency of the catathymic and imaginative method of dealing with inner conflicts of adolescents. The prospects of the further studies involve revealing the gender peculiarities of adolescents' inner conflicts.

Keywords: intrapersonal conflict, adolescence, catathymic and imaginative method, symboldrama, motive, method of semantic differential.

Подано до редакиії 29.04.2016

УДК: 159.9

Оксана Геннадіївна Шмиглюк, асистент кафедри сочіальної та практичної психології, Житомирський державний університет імені Івана Франка, вул. Велика Бердичівська, 40, м. Житомир, Україна

\section{ОСОБЛИВОСТІ УЯВЛЕНЬ УЧАСНИКІВ АТО ПРО СУЧАСНОГО УКРАЇНЦЯ}

У статті проаналізовано результати психосемантичного дослідження військовослужбовців щзодо категорії «українець» в рамках дослідження їх етнічної самосвідомості. Було виявлено переважаюче змістовне наповнення учасниками АТО поняття «украӥнець». У результаті контент-аналізу було виділено наступні типи асоціацій: асоціації, пов'язані з якісними характеристиками людини, емоційно-вольовими показниками, видатними постатями Украӥни, національними символами та традиціями України, патріотизмом, природнім середовищем, родиною, географічними показниками, державно-політичними процесами, релігійністю.

Ключові слова: свідомість, самосвідомість, етнічна самосвідомість, індивідуальний рівень етнічної самосвідомості, груповий рівень етнічної самосвідомості, учасник АТО, асоціативний експеримент.

Україна уже досить тривалий час знаходиться в ситуації постійної напруги, фрустрації та невизначеності. Такий стан в країні призводить до значних трансформацій, які, зокрема, стосуються переусвідомлення та переосмислення їі громадянами своїх життєвих цінностей, своїх ролей в тих суспільних процесах, які відбуваються в державі. Все більше спостерігається позитивна динаміка особистості у демонстрації своєї приналежності до української нації та етносу.

Учасники АТО безпосередньо включені в процеси змін та перебудов, які відбуваються в Україні. Тому науковий інтерес викликає питання: які уявлення про українця наявні в їх свідомості та чи можуть ці уявлення виступати мотиваційними факторами під час виконання військової служби.

Свідомість людини характеризується особливостями ii світорозуміння та світосприймання. Налаштованість на осмислення власних думок, почуттів і дій, здатність до рефлексії та самопізнання визначають самосвідомість людини. Якщо свідомість спрямовується на зовнішній світ, на інших людей та становить знання про них, то самосвідомість охоплює внутрішній світ людини (спільноти або особистості) [2].

Самосвідомість - усвідомлення людиною свого суспільного статусу і своїх життєво важливих потреб. Також, на основі аналізу психологічних досліджень, можна говорити про те, що самосвідомість особистості, як рефлексивний рівень їі свідомості, $\epsilon$ складним інтегративним процесом іiі самопізнання та емоційно-ціннісного самоставлення, на основі якого відбувається саморегуляція поведінки [4]. Отже, лю- дина як суб'єкт активності, визначається своєю здатністю усвідомлювати, відчувати та рефлексувати себе як особистість та як носія етносу та діяти у відповідності $з$ цим.

Етнічна самосвідомість - це уявлення індивіда чи цілої групи людей про себе чи образ свого етносу, які відображають знання про власну етнічну групу та ставлення до цієї групи. Етнічна самосвідомість виступає формою усвідомлення особистістю чи народом своєї належності до певного етносу, що базується на спільності мови, культури, історичної долі й визнанні особливих специфічно-історичних рис свого народу. Ключовим моментом етнічної самосвідомості є ідентифікація індивідів з певною етнічною спільністю, яка виявляється в самоназві. До неї долучається комплекс ідей чи уявлень, які утворюють систему етнодиференціюючих символів, що призводять до виокремлення членів своєї групи з усієї сукупності етнічних спільностей [3].

Вивченню проблеми етнічної самосвідомості присвячено праці багатьох науковців: Ю.В. Бромлея, М.Й. Боришевського, В.І. Козлова, П.І. Кушнір, В.Ю. Хотинець, Г.В. Шелєпова.

Хотинець В.Ю. визначає етнічну самосвідомість як відносно стійку систему усвідомлюваних уявлень i оцінок реально існуючих етнодиференціюючих та етноінтегруючих компонентів життєдіяльності етносу. Наслідком формування даної системи є усвідомлення людиною себе як представника певної етнічної спільності [5].

На думку В.I. Козлова, етнічна самосвідомість 